\title{
Effect of latitude on seasonal variations of vitamin D and some cardiometabolic risk factors: national food and nutrition surveillance
}

Bahareh Nikooyeh, ${ }^{1}$ Zahra Abdollahi, ${ }^{2}$ Nastaran Shariatzadeh, ${ }^{1}$ Ali Kalayi, ${ }^{1}$ Maliheh Zahedirad ${ }^{1}$ and Tirang Neyestani ${ }^{1}$

${ }^{1}$ Laboratory of Nutrition Research, National Nutrition and Food Technology Research Institute and Faculty of Nutrition Sciences and Food Technology, Shahid Beheshti University of Medical Sciences, Tehran, Islamic Republic of Iran. (Correspondence to: Tirang Neyestani: tneyestani@nnftri.ac.ir). ${ }^{2}$ Nutrition Office, Iran Ministry of Health, Treatment and Medical Education, Tehran, Islamic Republic of Iran.

\begin{abstract}
Background: Despite a remarkable reduction in the occurrence of many micronutrient deficiencies in most countries, vitamin D deficiency has remained a global problem. Age-adjusted disability-adjusted life years lost due to cardiovascular disease in the Eastern Mediterranean Region, including in the Islamic Republic of Iran, are higher than the global average.

Aims: To assess the effects of latitude and season on vitamin D status in the Iranian population and the association between vitamin D status and certain cardiometabolic risk factors.

Methods: A sample of 1111 participants aged 19-65 years was randomly selected from 6 regions with latitudes ranging from $29^{\circ} .0 \mathrm{~N}$ to $37.5^{\circ} \mathrm{N}$. All anthropometric and biochemical assessments were performed twice a year, summer and winter during 2013 to 2014 .

Results: Overall mean 25(OH)D concentration was 26.9 [standard deviation (SD) 17.8] nmol/L in winter and 43.4 (SD 32.9 $\mathrm{nmol} / \mathrm{L}$ in summer $(\mathrm{P}<0.001)$. Poor vitamin D status was noticeable in both seasons $(90.1 \%$ and $69.2 \%$, respectively). Being male (B, 7.6; 95\% CI: 4.3 to 10.8; $\mathrm{P}<0.001)$ and living at a latitude higher than $33^{\circ}$ were positive predictors, and serum $25(\mathrm{OH}) \mathrm{D}$ concentration in winter $(\mathrm{B},-0.2 ; 95 \% \mathrm{CI}:-2.9$ to $-0.11 ; \mathrm{P}<0.001)$ was a negative predictor of changes of $25(\mathrm{OH}) \mathrm{D}$ concentrations.

Conclusion: We found a high prevalence of suboptimal vitamin D status in Iranian adults throughout the year, irrespective of latitude and season. Improvement of mean circulating $25(\mathrm{OH}) \mathrm{D}$ concentrations in the community to $50+\mathrm{nmol} / \mathrm{L}$ through a fortification programme is likely to engender healthy cardiometabolic changes.

Keywords: vitamin D, seasonal variation, cardiometabolic risk factor, latitude

Citation: Nikooyeh B; Abdollahi Z; Shariatzadeh N; Kalay Ai; Zahedirad M; Neyestani T. Effect of latitude on seasonal variations of vitamin D and some cardiometabolic risk factors: national food and nutrition surveillance. East Mediterr Health J. 2021;27(3):269-278. https://doi.org/10.26719/emhj.20.119

Received: 30/01/19; accepted: 17/02/20

Copyright (c) World Health Organization (WHO) 2021. Open Access. Some rights reserved. This work is available under the CC BY-NC-SA 3.0 IGO license (https://creativecommons.org/licenses/by-nc-sa/3.o/igo).
\end{abstract}

\section{Introduction}

Despite a remarkable reduction in the occurrence of many micronutrient deficiencies in most, if not all, countries, vitamin D deficiency has remained a global nutritional problem (1). The importance of this single nutrient deficiency lies in its association with a wide range of human morbidities including cardiovascular disease (CVD), some types of cancers, autoimmune disorders like multiple sclerosis, diabetes and infectious diseases $(2,3)$.

Vitamin D is synthesized in skin from the conversion of the precursor 7-dehydrocholesterol under the influence of solar ultraviolet (UV) light. Several extrinsic and intrinsic factors, including clothing, latitude, season, time of day, socioeconomic status, age, skin type, use of sunscreen and amount of body fat, are important determinants of coetaneous vitamin D biosynthesis (4). Most common diets do not contain natural sources of vitamin $\mathrm{D}$ in appreciable amounts. Direct exposure to sunlight is, therefore, the main natural source (5).

Previous studies have demonstrated a seasonal variation in blood levels of $25(\mathrm{OH}) \mathrm{D}$, with lower concentrations in the late winter and early spring than in summer and early fall (6). In the northern hemisphere, decreased serum concentrations of $25(\mathrm{OH}) \mathrm{D}$ are seen in winter owing to inefficient UVB light. Consequently, from October to March, spending most of the daytime exposed to the sun does not guarantee optimal vitamin $\mathrm{D}$ status. The importance of this cold season fall in serum $25(\mathrm{OH}) \mathrm{D}$ would be more sizeable when considering that even in summer time, dermal biosynthesis of vitamin $\mathrm{D}$ might not be adequate due to such lifestyle factors as using sunscreens, reduced outdoor activity and abstinence of sun exposure due to fear of its potential health hazards (7).

Recently it has been reported that age-adjusted disability-adjusted life years due to CVD in the Eastern Mediterranean Region are higher than global average (8) and the Islamic Republic of Iran is no exception (9). Most of risk factors of CVD are modifiable and it has been estimated that by reducing CVD risk factors, some 100 million lives could be saved globally (10). Evidence obtained from prospective cohort studies indicates an increased risk of CVD in people with hypovitaminosis D as compared with those with sufficient status of vitamin D (11). Association between blood concentration of $25(\mathrm{OH})$ $\mathrm{D}$ and some cardiometabolic risk factors including obesity, hypertension, dyslipidaemia and inflammatory 
cytokines may suggest an explanation for the effect of vitamin D status on the development of CVD (12).

The prevalence of poor vitamin $\mathrm{D}$ status in the Islamic Republic of Iran, on the other hand, is alarming enough for the stakeholders to take an urgent action (13). Although the supplementation programme for school children and pregnant women has been implemented since a few years ago, several subpopulations including adults remained out of coverage umbrella. Sustainability of supplementation is another challenging issue. As a result, policy-makers at the Ministry of Health started evaluating different aspects of mass fortification of a staple food. To do this, some initial data were needed such as:

- Is vitamin D status affected by latitude, i.e. how does the prevalence of hypovitaminosis D vary in different latitudes?

- Is there a seasonal variation in vitamin D status?

- If yes, what is the range of circulating calcidiol concentration in different latitudes and overall?

- Is there any association between vitamin D status and certain cardiometabolic risk factors?

The answer to the last question was especially important as it implied the contribution of the vitamin D fortification programme in reducing the burden of CVD and probably many other related diseases.

To answer these questions, we longitudinally studied a sample of adult volunteers across a broad latitudinal range in the Islamic Republic of Iran.

\section{Methods}

\section{Participants}

The participants were part of the National Food and Nutrition Surveillance programme, a population-based study conducted during 2013-2014 by the Ministry of Health and the National Nutrition and Food Technology Research Institute and supported by UNICEF to examine and monitor the nutritional status of the Iranian population. This programme used a 2-stage cluster sampling design: there were 1683 clusters in West Azarbaijan, 1703 in Khoozestan, 1209 in South Khorasan, 1343 in Semnan, 1645 in Fars and 14212 in Lorestan. From each province, 12 clusters were selected randomly using probability-proportional-to-size, based on the population data from the 2012 census. After the selection of clusters, 20 households were chosen per cluster. All eligible people in the selected households were included in the programme. A sample of 1111 adults aged 19-65 years from both sexes were randomly selected from 6 regions of the country at different latitudes: West Azarbaijan $\left(37.5^{\circ} \mathrm{N}, 45.0^{\circ} \mathrm{E}\right)$, Semnan $\left(35.5^{\circ} \mathrm{N}, 53.3^{\circ} \mathrm{E}\right)$, Lorestan $\left(33.4^{\circ} \mathrm{N}, 48.3^{\circ} \mathrm{E}\right)$, South Khorasan $\left(32.8^{\circ} \mathrm{N}, 59.2^{\circ} \mathrm{E}\right)$, Khoozestan $\left(31.3^{\circ} \mathrm{N}, 48.6^{\circ} \mathrm{E}\right)$ and Fars $\left(29.6^{\circ} \mathrm{N}, 52.5^{\circ} \mathrm{E}\right)$.

The exclusion criteria were: intake of vitamin $\mathrm{D}$ or omega-3 supplements within the past 3 months; use of medications that could potentially influence vitamin
D metabolism within the past 3 months; any other concomitant clinical disease that could influence vitamin D metabolism (e.g. renal, hepatic, other endocrine disorders). The assessments of participants were done twice a year: summer (August-September) and winter (February-March) during 2013-2014.

\section{Questionnaire}

A general questionnaire comprising demographic data and sun exposure habits was completed for all participants via face-to face-interview carried out in the clinic by health workers; the average duration of the interview was 10-15 minutes. Sun exposure habits were evaluated based on duration of outdoor activity in a typical day and the usual time of outdoor activity (10.00 to 15.00, i.e. peak UV period in the day, and other times of day) (14). These questions were itemized in the questionnaire so that the duration of exposure ( $<10$ mins, 10-59 mins, 60-120 mins and $>120$ mins) as well as time of exposure (before 10.00, 10.00-15.00 and after 15.00) were specified by a checkmark in the relevant checkbox. However, in this study, the duration of exposure was divided into 2 categories, $<1$ and $\geq 1 \mathrm{hr} /$ day.

\section{Anthropometry}

Weight and height were measured by using a digital scale to the nearest $0.1 \mathrm{~kg}$ and a stadiometer to the nearest $0.1 \mathrm{~cm}$. Body mass index (BMI) was calculated as weight $(\mathrm{kg}) /$ height $(\mathrm{m})^{2}$. Overweight and obesity were categorized as BMI 25-30 and $>30 \mathrm{~kg} / \mathrm{m}^{2}$, respectively (15).

\section{Blood sampling and handling}

Blood samples were drawn in early morning following an overnight fast (12-14 hr). After 30-60 minutes at room temperature, sera were immediately recovered, aliquoted and stored at $-80^{\circ} \mathrm{C}$ until the day of analysis.

\section{Biochemical analyses}

Blood lipids: components of blood lipid profile [triglycerides (TG), total cholesterol (TC), low-density lipoprotein-cholesterol (LDL-C) and high-density lipoprotein-cholesterol (HDL-C)] were determined using commercial enzyme kits (Pars-Azmoon, Tehran, Islamic Republic of Iran) and an autoanalyser (Selecta E, Vitalab, Holliston, Netherlands).

Serum 25(OH)D: Serum concentrations of $25(\mathrm{OH})$ $\mathrm{D}$, calcidiol, were measured using a direct enzyme immunoassay (EIA, Diasource, Louvain-la-Neuve, Belgium). The EIA 25 (OH)D assay results were checked by high performance liquid chromatography to minimize between-method variation (16). The Laboratory of Nutrition Research has been participating in the Vitamin D External Quality Assessment Scheme (DEQAS) since 2008 and achieved the performance targets set by DEQAS.

In this study, vitamin D status was defined according to serum 25(OH)D concentrations as: deficiency < 25 $\mathrm{nmol} / \mathrm{L}$, insufficiency $25-50 \mathrm{nmol} / \mathrm{L}$ and sufficiency $>50$ $\mathrm{nmol} / \mathrm{L}(3)$. 
The combination of above normal BMI $(>25 \mathrm{~kg} /$ $\left.\mathrm{m}^{2}\right)$, suboptimal HDL-C concentration $(<40 \mathrm{mg} / \mathrm{dL}$ in males and $<50 \mathrm{mg} / \mathrm{dL}$ in females) and high serum TG concentration (> $150 \mathrm{mg} / \mathrm{dL}$ ) was defined as a cardiometabolic risk factor (CMRF) (17).

\section{Statistical analyses}

Mean and standard deviation were used to summarize continuous variables and frequencies were used for categorical variables. The Shapiro-Wilk test was used to check normality of distribution. Tests for differences in the continuous variables among latitudes were performed using analysis of variance (ANOVA) or KruskalWallis. Significant associations for categorical analyses were determined by chi-squared. The comparisons for changes in variables between the 2 seasons were made using the t-test for paired data or Wilcoxon's test, as appropriate. The effects of latitude $\left(\geq 33^{\circ} \mathrm{vs}<33^{\circ}\right)$ and sex on changes in $25(\mathrm{OH}) \mathrm{D}$ between summer and winter were examined using 2-way ANOVA. We also used 2-way multivariate ANOVA to assess the effect of latitude and sex on the combined changes in BMI and lipid profile variables. Pearson's correlation coefficient and multiple linear and logistic regression analyses were used to assess relationships between variables. Results were considered statistically significant at $P<0.05$. Statistical analyses were performed using SPSS, version 21.0.

\section{Results}

\section{Characteristics of the study population}

The distribution of serum $25(\mathrm{OH}) \mathrm{D}$, lipid profile and duration of sun exposure among the study sample according to sex and seasons are presented in Table 1. At the beginning of the study, the mean age of participants was 38.8 [standard deviation (SD) 8.1] years. No statistically significant difference was found for mean age between males and females [males: $39.1($ SD 7.9) years $(n=497)$; females: $38.5(S D 8.2)$ years $(n=614)(P=0.200)]$.

\section{Vitamin $D$ status and seasonal variation}

The overall mean 25(OH)D concentration was 26.9 (SD 17.8) $\mathrm{nmol} / \mathrm{L}$ in winter and 43.4 (SD 32.9) $\mathrm{nmol} / \mathrm{L}$ in summer $(P<0.001)$. Only in summer was there a statistically significant difference in the $25(\mathrm{OH}) \mathrm{D}$ concentration among latitudes with the lowest mean in Semnan and the highest in West Azarbaijan $(P<0.001)$ (Figure 1). For all latitudes, the occurrence of poor vitamin $\mathrm{D}$ status was remarkable in both seasons. Thus, in winter $90.1 \%$ of participants and in summer $69.2 \%$ had serum $25(\mathrm{OH}) \mathrm{D}$ concentrations below $50 \mathrm{nmol} / \mathrm{L}$. Using serum 25(OH)D concentrations below $75 \mathrm{nmol} / \mathrm{L}$ to describe undesirable vitamin D status, only $3.4 \%$ of the participants had sufficient status in winter and only $10.6 \%$ in summer.

About $23 \%$ of those with hypovitaminosis D $(<50$ $\mathrm{nmol} / \mathrm{L}$ ) in winter were in the sufficient category $(>50$ $\mathrm{nmol} / \mathrm{L}$ ) in summer. Prevalence of hypovitaminosis $\mathrm{D}$ showed a significant association with latitude only in summer, thus, people who resided in regions at latitude $<33^{\circ} \mathrm{N}$ had statistically significantly lower $25(\mathrm{OH}) \mathrm{D}$ concentrations compared with those living at $\geq 33^{\circ} \mathrm{N}$ latitude $(P=0.010)$ (Table 2).

In winter, the range of circulating concentrations of $25(\mathrm{OH}) \mathrm{D}$ was from 24.5 (SD 14.7) nmol/L in Semnan, $35.5^{\circ} \mathrm{N}$ with a cold semi-desert climate, to 29.5 (SD 20.7) $\mathrm{nmol} / \mathrm{L}$ in West Azarbaijan, $37^{\circ} \mathrm{N}$ with a Mediterranean climate and spring rains. However, the difference between these values was not statistically significant

Figure 1 Prevalence of vitamin D deficiency among adults in six provinces of the Islamic Republic of Iran in summer and winter
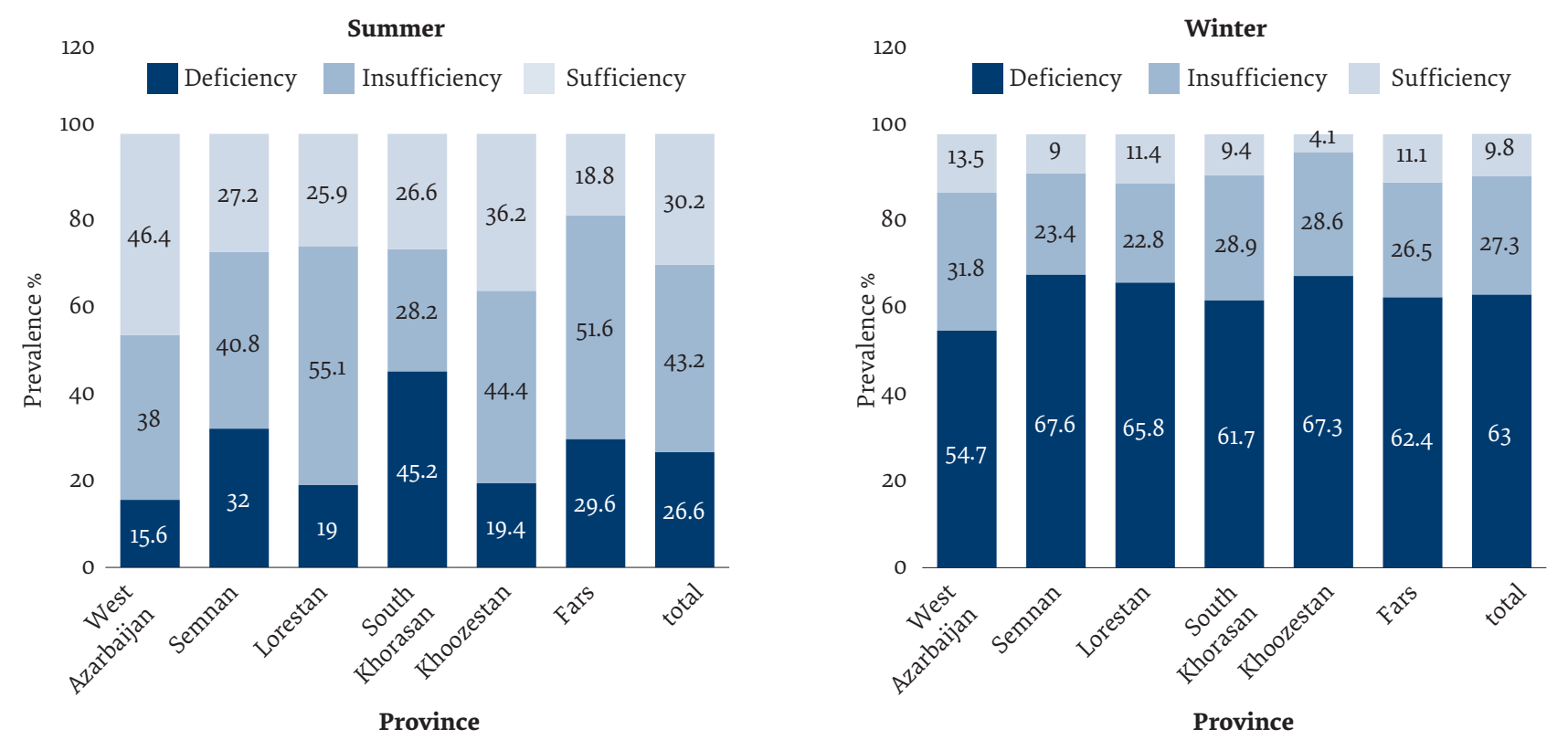

No. of participants is indicated within the bars; deficiency: $\leq 25 \mathrm{nmol} / \mathrm{L}$, insufficiency: $26-50 \mathrm{nmol} / \mathrm{L}$, sufficiency: $\geq 50 \mathrm{nmol} / \mathrm{L}$ 


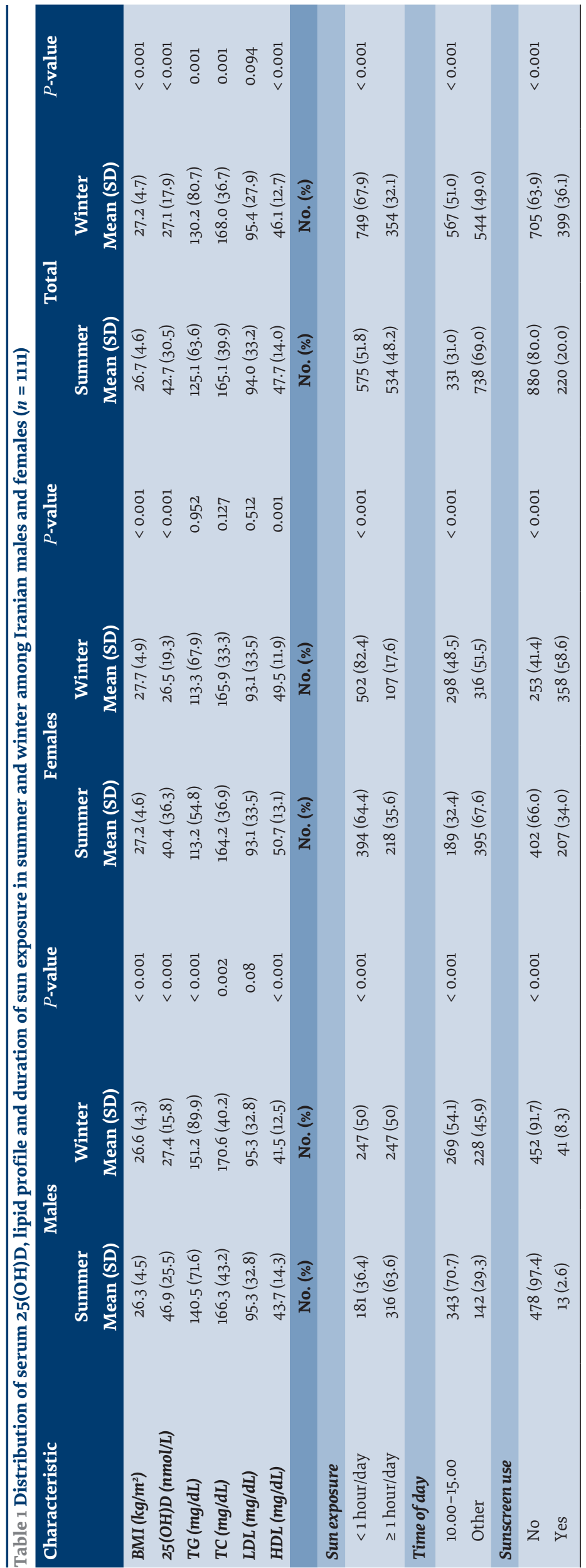

$(P=0.106)$. In summer, on the other hand, the lowest 25(OH)D concentrations were found in Khoozestan, latitude $31.3^{\circ} \mathrm{N}$ with a warm dry desert climate, and the highest concentrations in West Azarbaijan [37.1 (SD 34.5) vs 51.2 (SD 27.7) nmol/L; $P<0.001]$. Nevertheless, the prevalence of suboptimal vitamin D status was more or less similar for all latitudes during winter. The mean serum 25(OH)D concentration across the latitudinal gradient ranged from $24.5 \mathrm{nmol} / \mathrm{L}$ in winter to $51.2 \mathrm{nmol} / \mathrm{L}$ in summer.

The seasonal rise in circulating $25(\mathrm{OH})$ D showed no significant difference between provinces located at $<33^{\circ} \mathrm{N}(+14.2(\mathrm{SD} 28.6) \mathrm{nmol} / \mathrm{L})$ and $\geq 33^{\circ} \mathrm{N}(+17.3(\mathrm{SD} 25.3) \mathrm{nmol} / \mathrm{L})(P=0.061)$. Although in summer males had slightly, but statistically significantly, higher concentrations of $25(\mathrm{OH}) \mathrm{D}$ than females (46.9 (SD 25.5) vs 40.4 (SD 36.3) nmol/L; $P=0.001$ ), this difference was not observed in winter (27.4 (SD 15.8) vs 26.5 (SD 19.3); $P=0.370$ ). Moreover, the seasonal increase in $25(\mathrm{OH}) \mathrm{D}$ was statistically significantly greater in males than in females [+19.5 (SD 24.4) vs +12.4 (SD 28.9) nmol/L; $P<0.001]$. Accordingly, the duration of direct sun exposure in both seasons was greater in males than in females $(P<0.001)$ (Table 1). The serum concentrations of 25(OH)D in those who spent $\geq 1$ hour in sunlight were higher than in those who had shorter sun exposure ( $<1$ hour) [45.6 (SD 31.6) vs 41.3 (SD 32.4) nmol/L; $P=0.029$ ]. However, these differences were not observed in winter [26.9 (SD 15.9) vs 26.7 (SD 18.4) nmol/L; P $=0.888]$.

\section{Cardiometabolic risk factors}

There were significant seasonal changes in BMI $(P<0.001)$ and the components of blood lipids except for LDL-C. Prevalence of overweight/obesity were slightly but significantly higher in winter than in summer $(P<0.001)$. The occurrence rates of overweight/obesity in summer and winter were $62.5 \%$ (overweight: $39.1 \%$; obese: $23.4 \%$ ) and $66.4 \%$ (overweight: $40.9 \%$; obese: $25.5 \%$ ), respectively. Similarly, the prevalence of dyslipidaemia was higher in winter (Figure 2).

Two-way multivariate ANOVA showed that latitude (Wilks' Lambda $=0.987 ; P<0.001$ ) and sex (Wilks' Lambda $=0.916 ; P=0.003$ ) were both related to the combined changes of BMI and lipid profile components, but there was no interaction effect (Wilks' Lambda $=0.998 ; P=0.084$ ). In summer, the combination of dependent variables was associated with sex (Wilks' Lambda = 0.901; $P<0.001$ ) and vitamin D status (Wilks' Lambda $=$ $0.979 ; P=0.001$ ) and the post hoc analysis showed that those with undesirable vitamin $\mathrm{D}$ status ( $<50 \mathrm{nmol} / \mathrm{L}$ ) had higher BMI, serum TG, total cholesterol and LDL-C than those with desirable vitamin D status ( $\geq 50 \mathrm{nmol} / \mathrm{L}$ ). 
Table 2 Prevalence of vitamin D deficiency, insufficiency, and sufficiency by latitude and seasons

\begin{tabular}{llcccccc} 
Vitamin D status & \multicolumn{4}{c}{ Lower than $\mathbf{3 3 ^ { \circ }}$} & \multicolumn{2}{c}{ Latitude of residence } & \multicolumn{2}{c}{ All } \\
& \multicolumn{2}{c}{ summer } & winter & summer & winter & summer & winter \\
\hline Deficiency & $184(30.9)$ & $384(63.8)$ & $107(21.5)$ & $307(62.0)$ & $291(26.6)$ & $691(63.0)$ \\
Insufficiency & $252(42.3)$ & $168(27.9)$ & $220(44.3)$ & $131(26.5)$ & $472(43.2)$ & $299(27.3)$ \\
Sufficiency & $160(26.8)$ & $50(8.3)$ & $170(34.2)$ & $57(11.5)$ & $330(30.2)$ & $109(9.7)$ \\
\hline
\end{tabular}

$\mathrm{P}<0.001$ for all latitude categories.

The predefined CMRF was found in $4.1 \%$ of the participants in winter and $2.7 \%$ in summer. In winter, $36.4 \%$ of participants had at least 3 components of CMRF. However, this decreased to $26.0 \%$ in summer. In summer, the proportion of participants who had $\geq 3$ components of CMRF was higher among those with serum $25(\mathrm{OH})$ $\mathrm{D} l<50 \mathrm{nmol} / \mathrm{L}$ than among those with serum calcidiol concentrations $\geq 50 \mathrm{nmol} / \mathrm{L}(29.5 \%$ vs $18.5 \% ; P<0.001)$.

\section{Associations and predictors of 25-hydroxyvitamin D concentration}

Serum 25(OH)D was negatively associated with BMI in both winter and summer but only in summer was this association statistically significant $(r=-0.052 ; P=0.086$ vs $r=-0.092 ; P=0.002$, respectively).

There were weak but significant inverse correlations between seasonal changes in serum concentrations of 25(OH)D and those of BMI $(r=-0.088 ; P=0.004), \mathrm{TG}(r=$ -0.095; $P=0.002)$, TC $(r=-0.130 ; P<0.001)$ and LDL-C $(r$ $=-0.097 ; P=0.002)$. Summer rise in serum 25(OH)D did not differ between normal weight and overweight/obese people [16.2 (SD 25.3) vs 15.1 (SD 28.6) nmol/L; $P=0.533]$.
In multiple regression analysis, the most important predictors of serum $25(\mathrm{OH}) \mathrm{D}$ concentration in winter were $25(\mathrm{OH}) \mathrm{D}$ level in summer $(\mathrm{B}=0.3,95 \% \mathrm{CI}$ : 0.2 to 0.3 ; $P<0.001)$, age ( $B=0.2 ; 95 \% C I: 0.1$ to $0.3 ; P=0.001)$ and daily sun exposure between 10.00 and $15.00(B=2.3 ; 95 \%$ CI: 0.4 to $4.1 ; P=0.017)$. Sex, duration of sun exposure and $\mathrm{BMI}$ did not remain in the final model.

Two-way ANOVA revealed that changes in $25(\mathrm{OH})$ D were significantly associated with both latitude and sex $(P<0.001$ for both). No significant interaction between latitude and sex was found $(P=0.193)$. The logistic regression model (vitamin $\mathrm{D}$ status as dependent variable and BMI categories and sun exposure status as independent variables) after adjusting for age and sex, showed that in summer, odds of undesirable vitamin D status was $33 \%$ greater in people with BMI > 25 compared with normal weight participants (OR: 1.33, 95\% CI: 1.02 to $1.7 ; P=0.035$ ) and $39 \%$ less in those with $\geq 1$ hour a day solar exposure than those with $<1$ hour exposure (OR: $0.61,95 \%$ CI: 0.47 to $0.84 ; P<0.001$ ).

To determine the predictors of changes of $25(\mathrm{OH}) \mathrm{D}$ concentration in more detail, we carried out multivariate analyses. Being male (B, 7.6; $95 \% 95 \%$ CI: 4.3 to $10.8 ; P$

Figure 2 Prevalence of undesirable status of variables by seasons

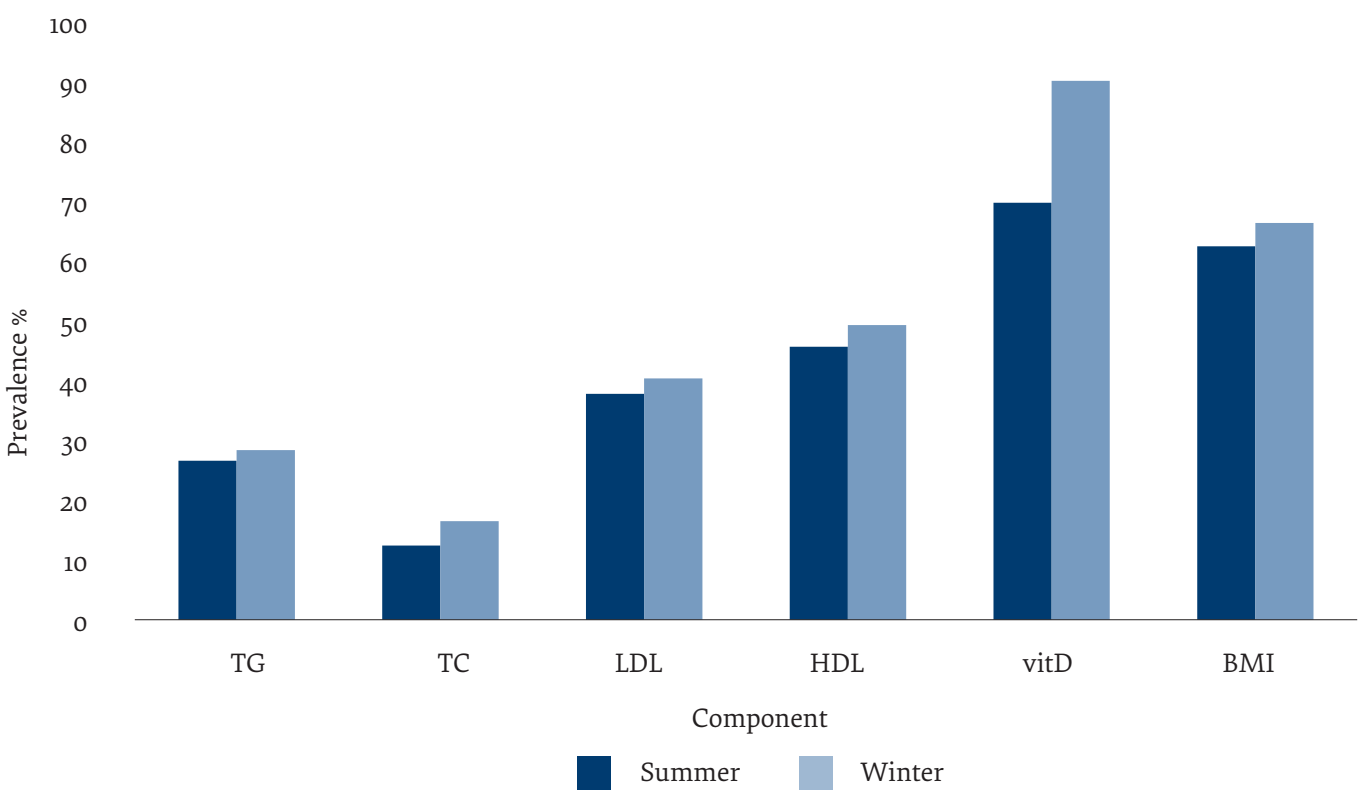

$\mathrm{TG}=$ triglycerides, $\mathrm{TC}=$ total cholesterol, $\mathrm{LDL}=$ low-density lipoprotein, $\mathrm{HDL}=$ high-density lipoprotein, vitD = vitamin $\mathrm{D}, \mathrm{BMI}=$ body mass index; No. of participants is indicated above the bars 
$<0.001$ ) and living in an area at latitude higher than $33^{\circ} \mathrm{N}$ (B, 3.8; 95\% 95\% CI: 0.5 to 7.0; $P=0.020$ ) were positive predictors. Serum $25(\mathrm{OH}) \mathrm{D}$ concentration in winter $(\mathrm{B}$, $-0.2 ; 95 \% 95 \%$ CI: -2.9 to $-0.11 ; P<0.001$ ) was a negative predictor of changes of $25(\mathrm{OH}) \mathrm{D}$ concentrations.

\section{Discussion}

To our knowledge, this is the first reported study of seasonality in the vitamin $\mathrm{D}$ status of adults in a broad latitudinal range and its relation to CMRF in the Islamic Republic of Iran. Our findings showed a widespread prevalence of hypovitaminosis $\mathrm{D}$ in both sexes residing in latitudes $29-37^{\circ} \mathrm{N}$, all year round. Despite a high prevalence of sub-desirable vitamin D status in both winter and summer and irrespective of latitude, there was a seasonal variation in concentration of circulating calcidiol.

Seasonal changes of circulating calcidiol concentrations have already been reported from many regions around the world including North Greenland with long winters and high solar zenith angle during summer $(18,19)$. A study of adolescent girls from Finland reported that mean 25(OH)D concentrations were highest in September (59.5 (SD 13.4) nmol/L) and lowest in February (37.3 (SD 15.5) nmol/L) (20). A study from Estonia (latitude $59^{\circ} \mathrm{N}$ ) also reported that the mean $25(\mathrm{OH}) \mathrm{D}$ in winter was 43.7 (SD 15.0) nmol/L, with only a third of the Estonian population showing sufficient vitamin D levels. A statistically significant increase in $25(\mathrm{OH})$ D concentration was observed in summer to 59.3 (SD 18.0) $\mathrm{nmol} / \mathrm{L}$ (18). This variation may be accompanied by associated changes in other health-related variables such as inflammatory biomarkers (21) and thyroid stimulating hormone (22). Even the outcome of communicable disease may somehow be influenced by this seasonal changes in concentrations of circulating calcitriol (23).

We found that exposure to sun for more than 1 hour per typical summer day was a predictor for sufficient vitamin D status. Nevertheless, in multiple linear regression, variation in sun exposure was a predictor of $25(\mathrm{OH}) \mathrm{D}$ concentration only in males not in females, who are mostly veiled in the Islamic Republic of Iran. We also found that suboptimal vitamin D status was common, even among people residing in a sunny climate like Khoozestan $\left(31.3^{\circ} \mathrm{N}, 48.6^{\circ} \mathrm{E}\right)$ and Fars $\left(29.6^{\circ} \mathrm{N}, 52.5^{\circ} \mathrm{E}\right)$. It is possibly due to "sunshine getaway" behaviour of people in those provinces due to hot weather at most times of the year. Hence, it seems that living in a sunny climate might be unconnected with the prevalence of hypovitaminosis $\mathrm{D}$.

Latitude affected 25(OHD) concentrations were mainly observed in summer months, during which vitamin $\mathrm{D}$ status was better in provinces located above $33^{\circ} \mathrm{N}$. The associations observed between latitude and vitamin D status have differed among studies. A metaanalysis of 394 studies demonstrated a significant decline in $25(\mathrm{OH}) \mathrm{D}$ concentrations with increasing latitude only in healthy white subjects but not in other ethnicities (24). It seems diversities in living conditions, including outdoor activities, clothing, sun-seeking behaviours and vitamin D intake (diet, fortified foods, supplements), can outweigh the effect of latitude (1).

We found a significant association between the changes in $25(\mathrm{OH}) \mathrm{D}$ levels and those of certain CMRF including BMI. However, the seasonal variation in serum 25(OH)D concentrations did not differ between normal weight people and overweight/obese people. The association of circulating $25(\mathrm{OH}) \mathrm{D}$ concentrations and CMRF has been already reported by some recent studies (25-27). Data from NHANES revealed that serum $25(\mathrm{OH}) \mathrm{D}$ concentrations and percentage of body fat or BMI were negatively related (28). Recently it was reported that serum calcidiol concentrations below 50 $\mathrm{nmol} / \mathrm{L}$ were associated with death from cardiometabolic factors in both normal weight and obese people (25). The Framingham study revealed that vitamin D status was associated with subcutaneous as well as visceral adiposity (29). A meta-analysis reported that the desirable serum $25(\mathrm{OH}) \mathrm{D}$ concentrations were associated with $43 \%$ reduction in cardiometabolic diseases, with a remarkable decrease in the occurrence of metabolic syndrome, type 2 diabetes and CVD, especially in the middle-aged and the elderly (30). However, another meta-analysis study conducted at almost the same time did not reach the same conclusion (31).

We found the serum 25(OH)D concentrations above $50 \mathrm{nmol} / \mathrm{L}$ may be associated with healthy changes in CMRF. However, another study proposed that the protective effects of vitamin $\mathrm{D}$ against cardiometabolic outcomes appear in serum 25(OH)D concentrations above $27.5-35 \mathrm{nmol} / \mathrm{L}$ (32), concentrations considered as insufficient.

Of very special interest was the concomitant seasonality of vitamin D status and CMRF. We found that physiological elevation in circulating $25(\mathrm{OH}) \mathrm{D}$ during summer was negatively paralleled by changes in serum concentrations of TG, LDL-C, TC and BMI. Seasonal changes in serum lipid profile (33) and glycaemic markers (34) have already been documented. Our findings boost the possibility of healthy changes of CMRF due to summer improvement in vitamin D status.

Despite there being several studies on the relationship between vitamin $\mathrm{D}$ and CVD, understanding of the connection is still lacking. Recent evidence suggests some pathways for the beneficial effect of vitamin D on the cardiovascular system, including decrease in renin-angiotensin-aldosterone system activity and antihypertensive, antiinflammatory, antiproliferative, antihypertrophic, and antithrombotic effects. It has also been shown that vitamin D may modify lipid profiles via increasing the activity of lipoprotein lipase in adipose tissue (35). Although some human studies have reported the beneficial effects of vitamin D on blood lipids and lipoproteins $(36,37)$, the current evidence is still insufficient and further well-designed studies are warranted $(38,39)$. 
Vitamin D seems to play a role in modulating adipogenesis by inhibiting such critical molecular components as peroxisome proliferator-activated receptor gamma 2 (PPAR- $\gamma 2$ ). Therefore, undesirable vitamin D status may cause additional differentiation of pre-adipocytes to adipocytes (40). Animal studies have reported the function of the vitamin in energy regulation (41). However, there is limited evidence to support this role in humans (42).

Some limitations of this study are acknowledged. We were not able to measure sun exposure directly. The sun exposure habits questionnaire was not validated in our country. However, we used this questionnaire in our previous studies with consistent results $(3,43)$. Additionally, actual intake of vitamin D from foods was not measured. However, previous studies have revealed that the typical Iranian diet is limited in natural sources of vitamin D (3).

\section{Conclusion}

In conclusion, we found firstly a high prevalence of suboptimal vitamin D status in Iranian adults throughout the year, irrespective of latitude and despite significant increase in circulating $25(\mathrm{OH}) \mathrm{D}$ concentrations in the warm season. Secondly, the summer increase in vitamin D status offered healthy changes in CMRF. Therefore, improvement in mean circulating $25(\mathrm{OH})$ concentration in the community to $\geq 50 \mathrm{nmol} / \mathrm{L}$ throughout the year via a national mass fortification programme is likely to bring about some healthy cardiometabolic changes. The expected increase in $25(\mathrm{OH}) \mathrm{D}$ due to consumption of fortified foods and drinks has been already evaluated $(3,43,44)$.

\section{Acknowledgement}

All laboratory bench work was performed at the Laboratory of Nutrition Research in the National Nutrition and Food Technology Research Institute. We wish to thank all participants for taking part in this project. We also appreciate our provincial contributors, their teams and the provincial deputies of health for their assistance, especially Somayeh Asghari, Fariba Babai, Fariborz Bojdi, Mostafa Hosseini, Razieh Shenavar, Mahnoosh Sahebdel, Ma'asoomeh Moradi and Sakineh Noori.

Funding: The National Food and Nutrition Surveillance programme is financially supported by UNICEF, the Community Nutrition Office of the Iranian Ministry of Health, and the National Nutrition and Food Technology Research Institute.

Competing interests: None declared.

\section{Effet de la latitude sur les variations saisonnières de la vitamine $D$ et certains facteurs de risque cardiométaboliques : surveillance nationale de l'alimentation et de la nutrition}

\section{Résumé}

Contexte: Malgré une réduction remarquable de la survenue de nombreuses carences en micronutriments dans la plupart des pays, la carence en vitamine D demeure un problème mondial. Les années de vie corrigées de l'incapacité standardisées en fonction de lâge perdues du fait de maladies cardio-vasculaires dans la Région de la Méditerranée orientale, y compris en République islamique d'Iran, sont plus élevées que la moyenne mondiale.

Objectifs : Évaluer les effets de la latitude et de la saison sur le bilan vitaminique D dans la population iranienne et l'association entre ce bilan et certains facteurs de risque cardiométaboliques.

Méthodes : Un échantillon de 1111 participants âgés de 19 à 65 ans a été sélectionné de façon aléatoire dans six régions ayant des latitudes comprises entre $29,0^{\circ} \mathrm{N}$ et $37,5^{\circ} \mathrm{N}$. Toutes les évaluations anthropométriques et biochimiques ont été réalisées deux fois par an, en été et en hiver, entre 2013 et 2014.

Résultats : La concentration générale moyenne en 25(OH)D était de $26,9 \mathrm{nmol} / \mathrm{l}$ en hiver [écart type (ET) 17,8] et $43,4 \mathrm{nmol} / \mathrm{l}(\mathrm{ET} 32,9)$ en été $(p<0,001)$. Un mauvais bilan vitaminique D a été observé au cours des deux saisons $(90,1 \%$ et $69,2 \%$, respectivement). Le fait d'être un homme (B : 7,6; IC à $95 \%: 4,3$ à 10,8; $p<0,001$ ) et de vivre à une latitude supérieure à 33 degrés représentaient des facteurs prédictifs positifs, et la concentration sérique en 25(OH)D en hiver (B : $-0,2$; IC à $95 \%:-2,9$ à $-0,11 p<0,001)$ était un facteur prédictif négatif des changements des concentrations en 25(OH)D.

Conclusion : Nous avons constaté une forte prévalence du bilan vitaminique D sous-optimal chez les adultes iraniens tout au long de l'année, indépendamment de la latitude et de la saison. L'amélioration des concentrations circulantes moyennes en 25(OH)D dans la communauté à plus de $50 \mathrm{nmol} / \mathrm{l}$ grâce à un programme d'enrichissement est susceptible d'engendrer des changements cardiométaboliques favorables à la santé. 


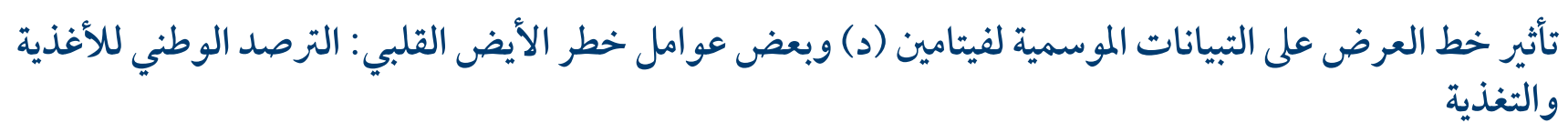

$$
\text { بهاريح نيقويا، زهرة عبد الله، ناستاران شريعة زادة، علي كالاي، مليحة زاهديارد، تيرانج نايستاني }
$$

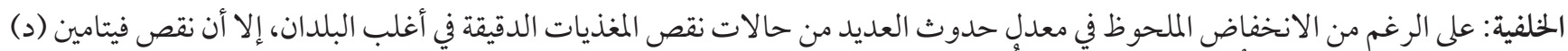

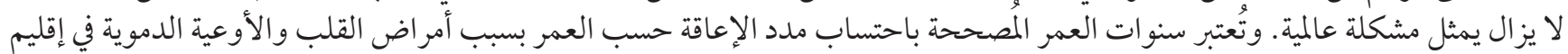

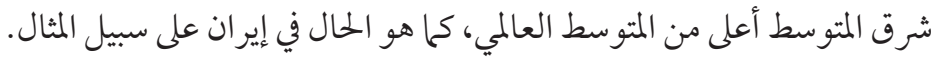

الأهداف: هدفت هذه الدراسة إلى تقييم آثار خط العرض والموسم على حالة فيتامين (د) لدى السكان الإيرانيين، والعلاقة بين حالة فيتامين (د) وبعض عوامل خطر الأيض القلبي.

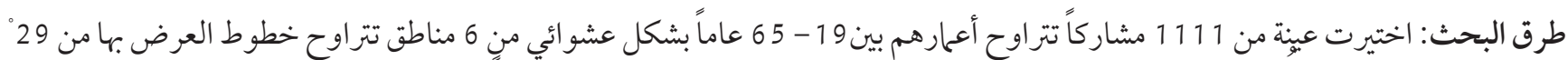

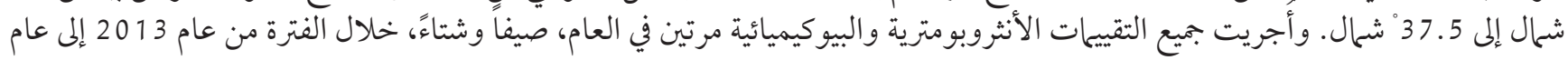

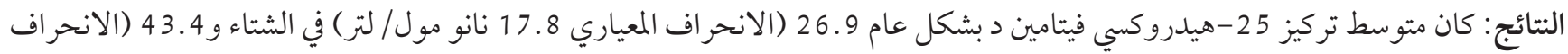

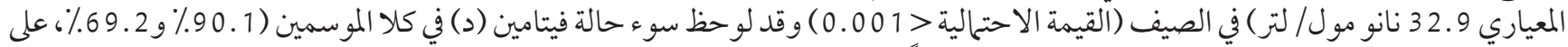

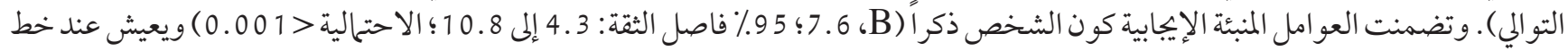

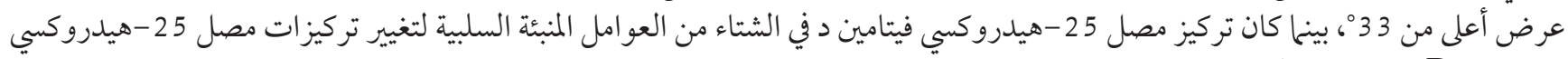

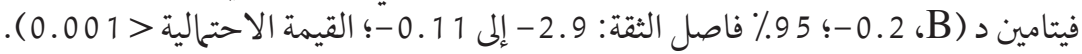

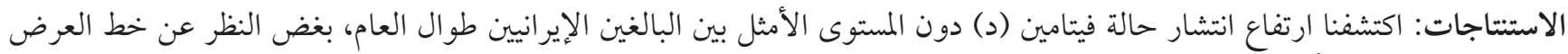

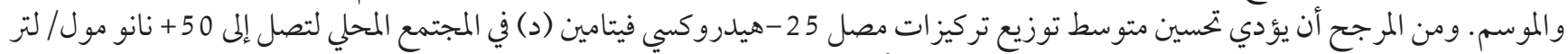

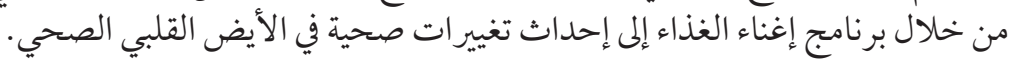

\section{References}

1. Mithal A, Wahl DA, Bonjour JP, Burckhardt P, Dawson-Hughes B, Eisman JA, et al. Global vitamin D status and determinants of hypovitaminosis D. Osteoporos Int. 2009 Nov;20(11):1807-20. doi:10.1007/s00198-009-0954-6

2. Holick MF. Vitamin D: importance in the prevention of cancers, type 1 diabetes, heart disease, and osteoporosis. Am J Clin Nutr. 2004 Mar;79(3):362-71. doi:10.1093/ajcn/79.3.362

3. Nikooyeh B, Neyestani TR, Farvid M, Alavi-Majd H, Houshiarrad A, Kalayi A, et al. Daily consumption of vitamin D- or vitamin $\mathrm{D}+$ calcium-fortified yogurt drink improved glycemic control in patients with type 2 diabetes: a randomized clinical trial. Am J Clin Nutr. 2011 Apr;93(4):764-71. doi:10.3945/ajcn.110.007336

4. Webb AR. Who, what, where and when-influences on cutaneous vitamin D synthesis. Prog Biophys Mol Biol. 2006;92(1):17-25. doi:10.1016/j.pbiomolbio.2006.02.004

5. Holick MF. Vitamin D: a D-Lightful health perspective. Nutr Rev. 2008 Oct;66(10 Suppl. 2):S182-94. doi:10.1111/j.17534887.2008.00104.x.

6. Macdonald HM, Mavroeidi A, Barr RJ, Black AJ, Fraser WD, Reid DM. Vitamin D status in postmenopausal women living at higher latitudes in the UK in relation to bone health, overweight, sunlight exposure and dietary vitamin D. Bone. 2008;42(5):996-1003. doi:10.1016/j.bone.2008.01.011

7. Sayre RM, Dowdy JC. Darkness at noon: sunscreens and vitamin D3. Photochem Photobiol. 2007;83(2):459-63. doi:10.1562/200606-29-RC-956

8. Mokdad AH. Burden of cardiovascular diseases in the Eastern Mediterranean Region, 1990-2015: findings from the Global Burden of Disease 2015 study. Int J Public Health. 2017 Aug 3. doi:10.1007/s00038-017-1012-3

9. Sadeghi M, Haghdoost AA, Bahrampour A, Dehghani M. Modeling the burden of cardiovascular diseases in Iran from 2005 to 2025: the impact of demographic changes. Iran J Public Health. 2017 Apr;46(4):506-16. PMID:28540267

10. Frieden TR, Jaffe MG. Saving 100 million lives by improving global treatment of hypertension and reducing cardiovascular disease risk factors. J Clin Hypertens (Greenwich). 2018 Feb;20(2):208-11. doi:10.1111/jch.13195

11. Anderson JL, May HT, Horne BD, Bair TL, Hall NL, Carlquist JF, et al. Relation of vitamin D deficiency to cardiovascular risk factors, disease status, and incident events in a general healthcare population. Am J Cardiol. 2010;106(7):963-8. doi:10.1016/j. amjcard.2010.05.027 
12. Wang H, Xia N, Yang Y, Peng D-Q. Influence of vitamin D supplementation on plasma lipid profiles: a meta-analysis of randomized controlled trials. Lipids Health Dis. 2012;11(1):1. doi:10.1186/1476-511X-11-42

13. Neyestani TR, Hajifaraji M, Omidvar N, Eshraghian MR, Shariatzadeh N, Kalayi A, et al. High prevalence of vitamin D deficiency in school-age children in Tehran, 2008: a red alert. Public Health Nutr. 2012 Feb;15(2):324-30. doi:10.1017/S1368980011000188

14. Chen TC, Chimeh F, Lu Z, Mathieu J, Person KS, Zhang A, et al. Factors that influence the cutaneous synthesis and dietary sources of vitamin D. Arch Biochem Biophys. 2007 Apr 15;460(2):213-7. doi:10.1016/j.abb.2006.12.017

15. Lee M, Ebert JR, Kadakia MP, Zhang J, Czerwinski SA. Inverse associations between cardiometabolic risk factors and 25-hydroxyvitamin D in obese American children and adolescents. Am J Hum Biol. 2016 Sep 10;28(5):736-42. doi:10.1002/ajhb.22863

16. Nikooyeh B, Samiee SM, Farzami MR, Alavimajd H, Zahedirad M, Kalayi A, et al. Harmonization of serum 25Dhydroxycalciferol assay results from high $\nabla$ performance liquid chromatography, enzyme immunoassay, radioimmunoassay, and immunochemiluminescence systems: a multicenter study. J Clin Lab Anal. 2017;31(6). doi:10.1002/jcla.22117

17. Nikooyeh B, Abdollahi Z, Hajifaraji M, Alavi-majd H, Salehi F, Yarparvar AH, et al. Vitamin D status and cardiometabolic risk factors across latitudinal gradient in Iranian adults: National food and nutrition surveillance. Nutr Health. 2017;23(2):87-94. doi:10.1177/0260106017702918

18. Kull M, Kallikorm R, Tamm A, Lember M. Seasonal variance of 25- $(\mathrm{OH})$ vitamin D in the general population of Estonia, a Northern European country. BMC Public Health. 2009;9(1):1. doi:10.1186/1471-2458-9-22

19. Andersen S, Jakobsen A, Laurberg P. Vitamin D status in North Greenland is influenced by diet and season: indicators of dermal 25-hydroxy vitamin D production north of the Arctic Circle. Br J Nutr. 2013 Jul 14;110(1):50-7. doi:10.1017/Soo07114512004709

20. Viljakainen HT, Palssa A, Kärkkäinen M, Jakobsen J, Cashman KD, Mølgaard C, et al. A seasonal variation of calcitropic hormones, bone turnover and bone mineral density in early and mid-puberty girls-a cross-sectional study. Br J Nutr. 2006;96(01):124-30. doi:10.1079/bjn20061719

21. Berry DJ, Hypponen E, Cortina-Borja M. Investigating the association of vitamin D seasonality on inflammatory and hemostatic markers. Chronobiol Int. 2013 Jul;30(6):786-95. doi:10.3109/07420528.2013.765888

22. Barchetta I, Baroni MG, Leonetti F, De Bernardinis M, Bertoccini L, Fontana M, et al. TSH levels are associated with vitamin D status and seasonality in an adult population of euthyroid adults. Clin Exp Med. 2015 Aug;15(3):389-96. doi:10.1007/s10238-0140290-9

23. Abhimanyu, Coussens AK. The role of UV radiation and vitamin D in the seasonality and outcomes of infectious disease. Photochem Photobiol Sci. 2017 Mar 16;16(3):314-38. doi:10.1039/c6ppoo355a

24. Hagenau T, Vest R, Gissel TN, Poulsen CS, Erlandsen M, Mosekilde L, et al. Global vitamin D levels in relation to age, gender, skin pigmentation and latitude: an ecologic meta-regression analysis. Osteoporos Int. 2009 Jan;20(1):133-40. doi:10.1007/s00198008-0626-y

25. Al-Khalidi B, Kimball SM, Kuk JL, Ardern CI. Metabolically healthy obesity, vitamin D, and all-cause and cardiometabolic mortality risk in NHANES III. Clin Nutr. 2019 Apr;38(2):820-8. doi:10.1016/j.clnu.2018.02.025

26. Cheng S, Massaro JM, Fox CS, Larson MG, Keyes MJ, McCabe EL, et al. Adiposity, cardiometabolic risk, and vitamin D status: the Framingham Heart Study. Diabetes. 2010;59(1):242-8. doi:10.2337/dbo9-1011

27. Reis JP, von Mühlen D, Miller ER, Michos ED, Appel LJ. Vitamin D status and cardiometabolic risk factors in the United States adolescent population. Pediatrics. 2009;124(3):e371-e9. doi:10.1542/peds.2009-0213

28. Yetley EA. Assessing the vitamin D status of the US population. Am J Clin Nutr. 2008 Aug;88(2):558S-64S. doi:10.1093/ajc$\mathrm{n} / 88.2 .558 \mathrm{~S}$

29. Cheng S, Massaro JM, Fox CS, Larson MG, Keyes MJ, McCabe EL, et al. Adiposity, cardiometabolic risk, and vitamin D status: the Framingham Heart Study. Diabetes. 2010 Jan;59(1):242-8. doi:10.2337/dbo9-1011

30. Parker J, Hashmi O, Dutton D, Mavrodaris A, Stranges S, Kandala NB, et al. Levels of vitamin D and cardiometabolic disorders: systematic review and meta-analysis. Maturitas. 2010 Mar;65(3):225-36. doi:10.1016/j.maturitas.2009.12.013

31. Pittas AG, Chung M, Trikalinos T, Mitri J, Brendel M, Patel K, et al. Systematic review: Vitamin D and cardiometabolic outcomes. Ann Intern Med. 2010 Mar 2;152(5):307-14. doi:10.7326/0003-4819-152-5-201003020-00009

32. Tepper S, Shahar DR, Geva D, Avizohar O, Nodelman M, Segal E, et al. Identifying the threshold for vitamin D insufficiency in relation to cardiometabolic markers. Nutr Metab Cardiovasc Dis. 2014 May;24(5):489-94. doi:10.1016/j.numecd.2013.10.025

33. Moura FA, Saraiva F, de Faria EC, Coelho OR, Sposito AC. Seasonal variation of lipid profile and prevalence of dyslipidemia: a large population study. J Am Coll Cardiol. 2013;61(10 Suppl.):1330-3. doi:10.1016/So735-1097(13)61330-3

34. Liang WW. Seasonal changes in preprandial glucose, $\mathrm{AlC}$, and blood pressure in diabetic patients. Diabetes Care. 2007 Oct;30(10):2501-2. doi:10.2337/dc07-0597

35. Mozos I, Marginean O. Links between vitamin D deficiency and cardiovascular diseases. BioMed Res Int. 2015;2015. doi:10.1155/2015/109275

36. Nkooyeh B, Neyestani T. Cholesterol and vitamin D: how the 'mother' and 'daughter' molecules interact. In: Watson RR, De Meester F, eds Handbook of cholesterol, biology, function and role in health and diseases. Wageningen, Netherlands: Wageningen Academic Publishers; 2016:256-65. 
37. Heravifard S, Neyestani TR, Nikooyeh B, Alavi-Majd H, Houshiarrad A, Kalayi A, et al. Regular consumption of both vitamin $\mathrm{D}$-and calcium-and vitamin D-fortified yogurt drink is equally accompanied by lowered blood lipoprotein (a) and elevated apoprotein Al in subjects with type 2 diabetes: a randomized clinical trial. J Am Coll Nutr. 2013;32(1):26-30. doi:10.1080/07315724. 2013.767659

38. Wang H, Xia N, Yang Y, Peng D-Q. Influence of vitamin D supplementation on plasma lipid profiles: a meta-analysis of randomized controlled trials. Lipids Health Dis. 2012;11(1):42. doi:10.1186/1476-511X-11-42

39. Challoumas D. Vitamin D supplementation and lipid profile: what does the best available evidence show? Atherosclerosis. 2014;235(1):130-9. doi:10.1016/j.atherosclerosis.2014.04.024

40. Duque G, Macoritto M, Kremer R. 1, $25(\mathrm{OH}) 2 \mathrm{D} 3$ inhibits bone marrow adipogenesis in senescence accelerated mice (SAM-P/6) by decreasing the expression of peroxisome proliferator-activated receptor gamma 2 (PPARУ2). Exp Gerontol. 2004;39(3):333-8. doi:10.1016/j.exger.2003.11.008

41. Wong KE, Szeto FL, Zhang W, Ye H, Kong J, Zhang Z, et al. Involvement of the vitamin D receptor in energy metabolism: regulation of uncoupling proteins. Am J Physiol Endocrinol Metab. 2009;296(4):E820-E8. doi:10.1152/ajpendo.90763.2008

42. Dix CF, Barcley JL, Wright OR. The role of vitamin D in adipogenesis. Nutr Rev. 2017;76(1):47-59. doi:10.1093/nutrit/nuxo56

43. Nikooyeh B, Neyestani TR, Zahedirad M, Mohammadi M, Hosseini SH, Abdollahi Z, et al. Vitamin D-fortified bread is as effective as supplement in improving vitamin D status: a randomized clinical trial. J Clin Endocrinol Metab. 2016 Jun;101(6):2511-9. doi:10.1210/jc.2016-163

44. Neyestani TR, Hajifaraji M, Omidvar N, Nikooyeh B, Eshraghian MR, Shariatzadeh N, et al. Calcium-vitamin D-fortified milk is as effective on circulating bone biomarkers as fortified juice and supplement but has less acceptance: a randomised controlled school-based trial. J Hum Nutr Diet. 2014 Dec;27(6):606-16. doi:10.1111/jhn.12191 